\title{
Repeatability of subjective grading in fur animals II. Grading of mink and blue fox pelts
}

\author{
HILKKA KENTTÄMIES and KeRSTIN SMEDS
}

\begin{abstract}
KentTÄMIES, H. \& SMEDS, K. 1992. Repeatability of subjective grading in fur animals. II. Grading of mink and blue fox pelts. Agric. Sci. Finl. 1: 309-314. (Univ. Helsinki, Dept. Anim. Breed., SF-00710 Helsinki, Finland.)

Repeatabilities for subjectively scored colour, clarity and quality traits as well as for measured and classified pelt sizes were studied in mink and blue fox pelts. Mink pelts appeared to be more difficult to grade than blue fox pelts. Among the scored traits, colour was found to be easiest to judge, while clarity as well as some pelt defects tended to be difficult to grade. Repeatabilities for size confirmed by measuring were greater as compared with the traits scored subjectively. Differences between repeatabilities attained by various persons were obvious.
\end{abstract}

Key words: pelt characteristics, pelt size, repeated evaluation

\section{Introduction}

Pelt characteristics are commonly graded subjectively. Pelt size is verified by measuring the length of pelt and therefore confirmed more objectively than the other traits. In addition, the judging of colour has been tested by optically determining the intensity of the colours. The pelt traits are classified into certain categories which are used in the sorting catalogues.

It is well established that grading the exterior traits of living animals is very difficult. On the other hand, it has often been assumed that pelt grading is exact and reliable because it is performed in more equal external conditions as compared with live animals. In previous studies, low to medium correlations between the quality traits graded in live animals and pelts have been found for minks (LAGERKVIST and LUNDEHEIM 1990, LOHI 1988, REITEN 1977) as well as for foxes (KENTTÄMIES 1987, 1988). High correlations were, however, obtained for colour.

This paper is one of a larger study on the accuracy of subjective grading in fur animals. The grading of live foxes was examined in a previous article (KENTTÄMIES and KÄYHKÖ 1992). The purpose of this investigation was to study the reliability of subjectively scored gradings for some pelt traits as well as for measured pelt size using repeated evaluation.

\section{Material and methods}

In April 1989 a repeatability test was done at Fur Center. The data consisted of 112 scanblack male mink pelts and 95 blue fox pelts. Three advisers from the Finnish Fur Animal Breeders' Association independently graded most of the pelts three times each. At each grading the following traits of the mink pelts were examined in the given order: quality, underfur density, guard hair density, colour, clarity and excistence and degree of the metallic 
pelt defect. The blue fox pelts were graded as follows: quality (at the same time it was recorded whether the pelts were heavy quality or not), colour, clarity, occurence and degree of the pelt defects: woolliness and silvery hairs.

There were model pelts for quality and colour at the judges' disposal. Quality was graded without taking pelt defects into consideration. The traits were graded in the scale presented in Table 1. The sizes were measured by three other persons. When the samples were analyzed, the repeatabilities were calculated for the size in cm:s as well as for the size classes.

Data were edited and analyzed using a statistical program WSYS (VILVA 1989). The effects of judge and time of grading on the traits were studied by the analysis of variance using the following fixed model:

Model 1:

$\mathrm{Y}_{\mathrm{ijk}}=\mu+\mathrm{a}_{\mathrm{i}}+\mathrm{b}_{\mathrm{j}}+\mathrm{e}_{\mathrm{ijk}}$ where $\mathrm{Y}_{\mathrm{ijk}}=$ individual observation

$\mu=$ generan mean

$a_{i}=$ effect of the ith judge, $i=1-3$

$b_{j}=$ effect of the jth time of grading, $j=1-3$

$\mathrm{e}_{\mathrm{ijk}}=$ random error

The repeatability coefficients of the traits were analyzed using random and mixed models. In the completely random model the effects of the judges were ignored and the data were analyzed using the following model:

Model 2:

$\mathrm{Y}_{\mathrm{ij}}=\mu+\mathrm{d}_{\mathrm{i}}+\mathrm{e}_{\mathrm{ij}}$ where $\mathrm{d}_{\mathrm{i}}=$ random effect of the $i$ th pelt with all other factors as described in Model 1.

The foregoing model was also used in analyzing repeatabilities by judges.

In order to eliminate the effect of judge as well as possible interactions between judge and pelt on the coefficients, the following hierarchic model was used:

Model 3:

$\mathrm{Y}_{\mathrm{ijk}}=\mu+\mathrm{a}_{\mathrm{i}}+\mathrm{d}_{\mathrm{ij}}+\mathrm{e}_{\mathrm{ijk}}$

where $d_{i j}=$ random effect of the $j$ th pelt within $i$ th judge

with all other factors as described in Model 1.

\section{Results and discussion}

\section{Means and standard deviations}

Means and standard deviations are shown in Table 2 . There existed more variation for quality among minks $(\mathrm{SD}=0.95)$ as compared with blue foxes $(\mathrm{SD}=0.73)$. In mink pelts, slightly larger variation was found for the separate quality traits, underfur density and guard hair density $(\mathrm{SD}=1.00$ to 1.03 ) in comparison with total quality. However, size of pelt determined by measuring seemed in each species to vary only to a minor degree $(\mathrm{SD}=3.47$ to 4.39). In mink pelts, only minor metallic pelt defects were found by each judge. Similarly, a slight degree of silvery hair was found in blue fox pelts.

Table 1. Grading of the pelt traits in minks and blue foxes.

\begin{tabular}{|c|c|c|}
\hline \multirow[t]{2}{*}{ Trait } & \multicolumn{2}{|c|}{ Scores } \\
\hline & Minks & Blue foxes \\
\hline Quality & 1 (II quality)-4 (Saga Selected) & 1 (I quality)-5 (Selected) \\
\hline Underfur density & 1 (poor)-4 (excellent) & \\
\hline Guardhair density & 1 (poor)- 4 (excellent) & \\
\hline Colour $^{1}$ & 1 (xx-dark)-4 (medium) & $2(x-$ dark $)-6(x x-$ pale $)$ \\
\hline Clarity & 1 (slightly off colour)-4 (clear colour) & 1 (off colour)-5 (clear colour) \\
\hline Pelt length & $\mathrm{cm}$ & $\mathrm{cm}$ \\
\hline Pelt size & $1(59.1-65.0 \mathrm{~cm})-4(77.1-83.0 \mathrm{~cm})$ & $1(88.1-97.0 \mathrm{~cm})-3(>106.1 \mathrm{~cm})$ \\
\hline
\end{tabular}

${ }^{1}$ In blue foxes the pelts of pale and x-pale colour combined in class 5 
Table 2. Number of observations (N), means and standard deviations (SD) for scores of the pelt traits studied in minks and blue foxes.

\begin{tabular}{|c|c|c|c|c|c|c|}
\hline \multirow[t]{2}{*}{ Trait } & \multicolumn{3}{|c|}{ Minks } & \multicolumn{3}{|c|}{ Blue foxes } \\
\hline & $\mathrm{N}$ & Mean & SD & $\mathrm{N}$ & Mean & SD \\
\hline Quality & 1008 & 2.72 & 0.95 & 854 & 2.33 & 0.73 \\
\hline Underfur density & 1005 & 2.32 & 1.00 & & & \\
\hline Guard hair density & 1005 & 2.47 & 1.03 & & & \\
\hline Colour & 1008 & 1.70 & 0.84 & 854 & 4.96 & 0.92 \\
\hline Clarity & 997 & 2.19 & 1.03 & 854 & 3.21 & 1.06 \\
\hline Pelt length, cm & 996 & 73.48 & 3.47 & 843 & 104.07 & 4.39 \\
\hline Pelt size, classes & 996 & 2.85 & 0.68 & 843 & 2.20 & 0.55 \\
\hline
\end{tabular}

\section{Effect of judge on the traits}

In minks and blue foxes, highly significant differences between judges in the traits were found, apart from the pelt size traits in blue foxes. When grading the quality of mink pelts, one of the judges followed a much stricter scale than the others. Large differences between judges appeared in the grading of clarity for both species. Obvious differences between judges to note pelt defects were found as well. Differences between standards of judgment have been previously found among mink skins (REITEN 1977), live minks (MACIEJOWSKI and SŁAwoŃ 1973) and live silver foxes (KENTTÄMIES and KÄYHKÖ 1992).

\section{Repeatabilities of grading}

It appeared to be more difficult to grade mink pelts than blue fox pelts. Among each species higher coefficients of repeatability were obtained when differences between judges were taken into account (a hierarchic model) as compared with those analysed within pelts (Table 3 ). However, both models gave repeatabilities of the same magnitude for colour in minks and quality in blue foxes. Therefore these traits seem to be easier to grade than the others.

Colour was the trait which was easiest to grade, the repeatabilities were 0.65 in minks and 0.82 in blue foxes (Table 3). The respective repeatabilities

Table 3 . The repeatability coefficients \pm standard errors for pelt traits in dark mink and blue fox.

$\mathrm{N}=991$ (minks), 852 (blue foxes)

\begin{tabular}{|c|c|c|c|c|}
\hline \multirow[t]{2}{*}{ Trait } & \multicolumn{2}{|c|}{$\begin{array}{c}\text { Minks } \\
\text { Repeatabilities } \pm \text { Standard errors }\end{array}$} & \multicolumn{2}{|c|}{$\begin{array}{c}\text { Blue foxes } \\
\text { Repeatabilities } \pm \text { Standard errors }\end{array}$} \\
\hline & Within pelt & $\begin{array}{l}\text { Within judge } \\
\text { and pelt }\end{array}$ & Within pelt & $\begin{array}{l}\text { Within judge } \\
\text { and pelt }\end{array}$ \\
\hline Quality & $0.36 \pm 0.04$ & $0.59 \pm 0.03$ & $0.70 \pm 0.03$ & $0.74 \pm 0.02$ \\
\hline Underfur density & $0.49 \pm 0.04$ & $0.61 \pm 0.03$ & & \\
\hline Guard hair density & $0.41 \pm 0.04$ & $0.56 \pm 0.03$ & & \\
\hline Colour & $0.63 \pm 0.04$ & $0.65 \pm 0.03$ & $0.70 \pm 0.03$ & $0.82 \pm 0.02$ \\
\hline Clarity & $0.35 \pm 0.04$ & $0.48 \pm 0.03$ & $0.53 \pm 0.04$ & $0.62 \pm 0.03$ \\
\hline Pelt length, $\mathrm{cm}$ & $0.95 \pm 0.01$ & $0.97 \pm 0.003$ & $0.83 \pm 0.02$ & $0.83 \pm 0.02$ \\
\hline Pelt size, classes & $0.87 \pm 0.02$ & $0.93 \pm 0.01$ & $0.77 \pm 0.03$ & $0.78 \pm 0.02$ \\
\hline Metallic & $0.38 \pm 0.04$ & $0.47 \pm 0.03$ & & \\
\hline Heavy type & & & $0.42 \pm 0.04$ & $0.58 \pm 0.03$ \\
\hline Woolliness & & & $0.55 \pm 0.04$ & $0.65 \pm 0.03$ \\
\hline Silvery hair & & & $0.17 \pm 0.03$ & $0.44 \pm 0.04$ \\
\hline
\end{tabular}


Table 4 . The repeatability coefficients \pm standard errors for the pelt traits of dark mink and blue fox graded by various judges.

\begin{tabular}{|c|c|c|c|c|c|c|}
\hline \multirow[t]{2}{*}{ Trait } & \multicolumn{3}{|c|}{$\begin{array}{c}\text { Minks } \\
\text { Repeatabilities } \pm \text { Standard errors }\end{array}$} & \multicolumn{3}{|c|}{$\begin{array}{c}\text { Blue foxes } \\
\text { Repeatabilities } \pm \text { Standard errors }\end{array}$} \\
\hline & Judge 1 & Judge 2 & Judge 3 & Judge 1 & Judge 2 & Judge 3 \\
\hline Quality & $0.59 \pm 0.05$ & $0.57 \pm 0.05$ & $0.60 \pm 0.05$ & $0.66 \pm 0.05$ & $0.79 \pm 0.03$ & $0.80 \pm 0.03$ \\
\hline Underfur density & $0.60 \pm 0.05$ & $0.56 \pm 0.05$ & $0.68 \pm 0.04$ & & & \\
\hline Guard hair density & $0.57 \pm 0.05$ & $0.63 \pm 0.05$ & $0.48 \pm 0.06$ & & & \\
\hline Colour & $0.72 \pm 0.04$ & $0.69 \pm 0.04$ & $0.54 \pm 0.05$ & $0.90 \pm 0.02$ & $0.77 \pm 0.03$ & $0.83 \pm 0.03$ \\
\hline Clarity & $0.46 \pm 0.06$ & $0.62 \pm 0.05$ & $0.38 \pm 0.06$ & $0.54 \pm 0.06$ & $0.66 \pm 0.05$ & $0.62 \pm 0.05$ \\
\hline Pelt length, $\mathrm{cm}^{1}$ & $0.99 \pm 0.002$ & $0.95 \pm 0.01$ & $0.98 \pm 0.003$ & $0.88 \pm 0.02$ & $0.78 \pm 0.03$ & $0.83 \pm 0.03$ \\
\hline Pelt size, classes ${ }^{1}$ & $0.94 \pm 0.01$ & $0.92 \pm 0.01$ & $0.93 \pm 0.01$ & $0.79 \pm 0.03$ & $0.71 \pm 0.04$ & $0.83 \pm 0.03$ \\
\hline Metallic & $0.54 \pm 0.05$ & $0.42 \pm 0.06$ & $0.49 \pm 0.06$ & & & \\
\hline Heavy type & & & & $0.59 \pm 0.05$ & $0.49 \pm 0.06$ & $0.64 \pm 0.05$ \\
\hline Woolliness & & & & $0.69 \pm 0.04$ & $0.53 \pm 0.06$ & $0.77 \pm 0.03$ \\
\hline Silvery hair & & & & $0.46 \pm 0.06$ & $0.42 \pm 0.06$ & $0.43 \pm 0.06$ \\
\hline
\end{tabular}

'Judges 4, 5 and 6

of colour obtained by the different judges varied from 0.54 to 0.72 and from 0.77 to 0.90 (Table 4). This is in line with previous studies for minks (JONSSON 1971, REITEN 1977, JEŻEWSKA and MACIEJOWSKI 1982) as well as for live blue foxes (JEŻEWSKA and MACIEJOWSKI 1982). Clarity was found to be one of the most difficult traits to grade, the repeatability was $0.48(0.38-0.62$ by judges $)$ in minks and $0.62(0.54-0.66)$ in blue foxes. In addition, scores for heavy type in foxes appeared to be difficult to repeat, the estimate was 0.58 ( $0.49-0.64$ by judges).

The repeatability for quality was on average 0.59 $(0.57-0.60$ by judges) in minks and 0.74 ( $0.66-0.79$ by judges) in blue foxes. Similar results for quality or general appearance without taking body size into consideration have been previously found in live minks (JEŻEWSKA and MACIEJOWSKI 1982, Børsting and Clausen 1986) as well as in living blue foxes (JEŻEWSKA and MACIEJOWSKI 1982). An estimate obtained by JEŻEWSKA and MACIEJOWSKI (1982) in one series of blue foxes was, however, much lower than in another. The grading of mink pelts for density in underfur gave higher repeatabilities $(0.61,0.56-0.68$ by judges) as compared with guard hairs $(0.56,0.48-0.63$ by judges). These results accord with studies of
REITEN (1977) in dark mink skins. On the other hand JEŻEWSKA and MACIEJOWSKI (1982) obtained variable repeatabilities for hair thickness and hair length in live minks and two samples of blue foxes.

Existence of pelt defects, metallic sheen in minks and woolliness and silvery hair in foxes were found difficult to grade. Differences between judges in ability to repeat the grading for the existence and degree of pelt defects were obvious. The repeatability for metallic sheen was 0.47 (0.42-0.54 by judges). REITEN (1977), however, received higher correlations between two independent gradings for the sheen. When grading woolliness and silvery hair in foxes, the judges followed very different scales. The repeatability for woolliness was 0.65 and varied from 0.53 to 0.77 among judges. A fairly low, although less variable estimate was obtained for silvery hair $(r=0.44$, $0.42-0.46$ by judges).

The repeatabilities for measured pelt length were 0.97 for mink pelts and 0.83 for blue fox pelts. Similar results for length of mink pelts were reported by REITEN (1977). In the present study the repeatabilities obtained by various persons were much the same $(r=0.95-0.99$ for minks vs. $r=0.78-0.88$ for blue foxes). Slightly lower repeatabilities were obtained for pelt size classified in size categories as 
compared with the measured length, the estimates were 0.93 ( $0.92-0.94$ by judges) for minks and 0.78 $(0.71-0.83)$ for blue foxes.

None of the judges produced much better results than others, all the judges obtained their highest repeatabilities for some traits and their lowest ones for various other traits.
Acknowledgements. The authors want to thank Pekka Petman, Simo Paavola and Raimo Reijonen, Finnish Fur Breeders' Association for carefully grading pelts. Veijo Vilva is acknowleged for fruitful discussions during the statistical analysis, and prof. Matti Ojala for valuable comments on the manuscript. Financial support was received from the Technology Development Centre (TEKES).

\section{References}

Børsting, E. \& Clausen, J. 1986. Anvendelse av livdyrvurdering i minkavel. NJF Utredning/Rapport no. 27, 5 p.

JEŻEWSKA, G. \& MACIEJOWSKI, J. 1982. Repeatability of exterior trait estimations in different species of fur animals. 33rd EAAP, Leningrad. 16.-19.9.1982, 9 p.

JoNSSON, M.B. 1971. Variasjonsårsaker for noen produksjonsegenskaper hos mink. Meld. Norg. Landbr.høgsk. 50 no. $6,47 \mathrm{p}$.

KENTTÃMIES, H. 1987. Gradering av levande blårăvar. NJFSymposium no. 128, Tromsø. 28.-30.9.1987. 8 p.

- 1988. Heritability of body size and fur quality in foxes Vulpes vulpes. In: Murphy, B.D. \& Hunter, D.B. (eds.). Biology, Pathology and Genetics of Fur Bearing Animals. Proc. IV Int. Congr. Fur Anim., Toronto, Canada. p. 548-556.

— \& KӒҮнКО人, H. 1992. Repeatability of subjective grading in fur animals. I. Grading of live silver foxes. Agric. Sci. Finl. 1: 303-307.

LAGERKVIST, G. \& LundeHEIM, L. 1990. Fur quality traits in Standard mink-Price relationships, heritabilities and genetic and phenotypic correlations. Acta Agric. Scand. 40: 367-376.

LOHI, O. 1988. Selection for fur density and guard hair quality in Scanblack mink. In: Murphy, B.D. \& Hunter, D.B. (eds.). Biology, Pathology and Genetics of Fur Bearing Animals. (Proc. IV Int. Congr. Fur Anim., Toronto, Canada. September 21.-24.1988), p. 464470.

MACIEJOWSKI, J. \& S $ł$ Awón, J. 1973. Subjectivity of licence estimations of Standard minks as the source of mistakes in breeding. Prace i Materialy Zootechn. 4: 64-82.

REITEN, J. 1977. Korrelasjoner mellom gjentatte målinger og vurderinger av pelsegenskaper hos mørk mink. Meld. Norg. Landbr.høgsk. 56, no. 14, 15 p.

VILVA, V. 1989. Statistical microcomputer program WSYS. Univ. Helsinki, Dept. Anim. Breed.

Manuscript received December 1991

Hilkka Kenttämies

Kerstin Smeds

University of Helsinki

Department of Animal Breeding

SF-00710 Helsinki, Finland

Kerstin Smeds

Present adress:

Finnish Fur Breeders' Association

Box 5, SF-06101 Vantaa, Finland 


\title{
SELOSTUS
}

\section{Turkiseläinten subjektiivisen arvostelun toistettavuus II. Minkkien ja sinikettujen nahka-arvostelu}

\author{
HilkKa Kenttämies ja Kerstin SmedS \\ Helsingin yliopisto
}

\begin{abstract}
Minkkien ja sinikettujen nahka-arvostelun toistettavuutta tutkittiin Turkistuottajat Oy:n nahkavarastolla Vantaalla. Minkit olivat peräisin Suomen Turkiseläinten Kasvattajain Liitto ry:n Veikkolan koetarhalta ja siniketut Maksamaan koetarhalta. Urospuolisia, scanblack-värityyppiä olevia minkinnahkoja oli yhteensä $112 \mathrm{kpl}$ ja siniketunnahkoja 95 $\mathrm{kpl}$. Kolme arvosteluun tottunutta henkilöä arvosteli nahat itsenăisesti kolmeen kertaan. Kolme muuta henkilöă mittasi nahat. Minkeiltä arvosteltiin laatu, massakkuus, peittävyys, värin tummuus ja puhtaus sekä mahdollinen metallinkiillon esiintyminen ja sen vaikeusaste. Siniketuilta arvosteltiin
\end{abstract}

laatu (samalla tarkistettiin oliko nahka massakasta heavytyyppiä), värin tummuus ja puhtaus sekä mahdollisista nahkavirheistä villaisuuden ja hopeakarvan esiintyminen ja vaikeusaste. Minkinnahat osoittautuivat vaikeammin arvosteltaviksi kuin ketunnahat. Subjektiivisesti arvostelluista ominaisuuksista värin tummuus oli helpoin ja värin puhtaus eräiden nahkavirheiden ohella vaikein ominaisuus arvostella. Mittaamalla todettujen nahan pituuksien toistettavuudet olivat parempia kuin silmävaraisesti pistein arvosteltujen ominaisuuksien toistettavuudet. Myös eri arvostelijoiden saavuttamissa tuloksissa oli eroja. 